\title{
Eddie Murphy's Baby Mama Drama and Smith Family Values: The (Post-) Racial Familial Politics of Hollywood Celebrity Couples \\ Hannah Hamad
}

I really believe that a man and a woman together, raising a family, is the purest form of happiness we can experience. Will Smith, The Voice, 1997.

We're not together any more. And I don't know whose child that is until it comes out and has a blood test. Eddie Murphy, RTL Boulevard, 2006.

I had people calling me a gold digger, saying that I got pregnant on purpose. It was a horrible time. Melanie Brown, 'Mel B: Spice Mom', Mel B: It's a Scary World (Style Network, 2010)

When Barack Obama delivered his keynote address to assembled delegates of the Democratic National Convention on July 27, 2004, asserting 'There's not a black America and white America and Latino America and Asian America; there's the United States of America, ${ }^{1}$ it not only signalled his imminent rise to prominence within the Democratic Party, it also heralded a shift toward the cultural and political normalization of post-racial discourse, culminating in Obama's election to the presidency on November 4, 2008 as the first person of color to hold this office in the nation's racially charged history. Through espousal of rhetoric that purports not to see racial difference, Obama's election was, as racial justice advocate Tim Wise argues, achieved in part on the back of 'a rhetoric of racial transcendence' and an 'agenda of colorblind universalism.'2

Also symptomatic of the purported end of racial discourse in popular culture was Forbes' naming of cross-media celebrity Will Smith as the highest paid actor in Hollywood in $2008 .^{3}$ Smith was also voted most bankable star of that year in the annual film exhibitors' poll conducted by the International Motion Picture Almanac. ${ }^{4}$ He was only the third African American to attain this 
level of stardom by the latter measure, and the first since Eddie Murphy, himself the third highest paid actor in Hollywood in the year of Obama's election, ${ }^{5}$ who topped the poll in 1987.6 Hence, as arguably the biggest African American stars in Hollywood during the period leading up to the Obama presidency and beyond, the celebrity identities of Will Smith and Eddie Murphy, as they pertain to the politics of racial discourse at the dawn of the Obama era, are charged with meaning. This comes into clearest view when seen through the frame of coupledom and familial politics, as articulated through the public identities and personae of these stars. The cultural politics of coupledom and family have always been particularly racially charged spheres of debate where African Americans have been the subjects. And as encapsulated in the epigraphs that open this chapter, the opposing extents to which Smith and Murphy are seen through mediation of their romantic relationships and their attendant selfconceptualizations as fathers to espouse and live up to normative family values, are highly revealing of their embodiments of (post) racial discourse.

Smith, partnered by wife and fellow Hollywood actor Jada Pinkett Smith, was hailed during this time as the emblematically post-racial star for Obama's America, and the Smiths, including children Jaden and Willow, as a model family. Whereas Murphy, whose persona always carried more overt racial charge than Smith's but whose image had been recuperated as racially benign and family oriented by the early 2000s, became embroiled in a highly publicized paternity dispute. This followed his brief relationship with British singer and reality star Melanie Brown, best known in the 1990s as a member of girl group The Spice Girls. And its mediation positioned his celebrity alongside damaging stereotypes of African American family life, divesting his persona of the veneer of 
colorblindness and racial transcendence that had heretofore characterized this phase of his career. This chapter therefore explores the racial and post-racial cultural politics of coupledom and family as they pertain to the celebrity discourse surrounding Will Smith and Eddie Murphy at the germination of the Obama era. It argues that, notwithstanding claims made for their racial transcendence or colorblind appeal to crossover audiences, both stars remain firmly located within the discourse of race, which manifests differently through mediated dynamics of coupledom and family.

In his discussion of the relationship between post-racial discourse and celebrity culture, Ellis Cashmore makes clear what is at stake in this dialogue writing that

black celebrities have sold the idea that America is no longer manacled to... a history pockmarked by racism, segregation and victimization. Undeniable progress since civil rights has promoted the ideal of what many call the postracial society, a place where racism and other forms of bigotry have no purchase. The election of Barack Obama, himself a political celebrity..., seemed to validate if not the arrival, then the imminence of the postracial society. ${ }^{7}$

It would therefore be injudicious to interrogate the U.S. cultural politics of celebrity coupledom and race since the mid-2000s without acknowledging the semiotic power of Barack and Michelle Obama, along with their children Malia and Sasha, and the extent to which mediation of this family set a new benchmark for the widespread negotiation of post-racial discourses of colorblindness and 
racial transcendence in celebrity culture. As an upshot of their pre-election mediation, the Obamas joined the pantheon of couples fuelling the economy of the cross-media celebrity gossip industries, across the spectrum of relative levels of cultural distinction, ranging from tabloid to top-end journalism and the lowest to highest forms of cultural criticism. Noteworthy examples from the higher end that underscore the extent of the cultural valence of the Obamas' celebrity coupledom include Time's decision to feature Michelle in its recurring 'Celebrity Spotlight' cover feature in May 2009, ${ }^{8}$ and Jodi Kantor's profile of the first couple for The New York Times Magazine in October 2009. ${ }^{9}$ At the other end, People profiled 'The Obamas at Home' in August 2008,10 while US Weekly showcased the couple under the banner 'Why Barack Loves Her' in June 2008. ${ }^{11}$ As Caroline Streeter states in her explanation of how such media imagery of the Obamas was harnessed on the campaign trail:

Obama's charm was legendary, yet consistently chaste. His wife... beautiful, intelligent, articulate, along with attractive and appealing daughters... seemed a made-to-order first black family. Obama's embodiment of ideal husband and father put him above reproach without dimming his sex appeal.'12

But pointing to what was at stake in doing so, Angela Nelson highlights that much of the post-racial charge of mediating the Obamas in terms of their coupledom and as a normatively configured family, lies in the function of such imagery to 'allow America to see a functional (rather than dysfunctional) black family,'13 at odds with entrenched and pernicious rhetoric that paints and pathologizes the black family as perennially 'in crisis.' Since the publication of sociologist E. Franklin Frazier's The Negro Family in the United States in 1939,14 
followed by the infamous Moynihan report The Negro Family: The Case for National Action in 1965,15 and the 1995 'Million Man March' on Washington by massed African Americans organized by Nation of Islam leader Louis Farrakhan (the major flashpoint of the 1990s fatherhood responsibility movement), African Americans have come under fire as deficient from family values proselytizers. Over time, evidence of this purported absence of family values has been attributed to births out of wedlock, a correspondingly high proportion of single mothers with attendant dependency on welfare, matriarchal kinship networks, and chronic levels of fatherlessness, paternal irresponsibility and domestic violence, often linked to the high numbers of African American men in the US prison system. Perniciously gendered and racialized cultural stereotypes of African American families thus emerged from this 'crisis' rhetoric. It is in this context that the media framing of the (post-) racial familial politics of Murphy/Brown and the Smiths must be understood.

\section{Eddie Murphy's Baby Mama Drama}

The Murphy/Brown paternity scandal unfolded in a post-Katrina America, newly reminded in catastrophic circumstances of the urgent need to see and acknowledge racial discourse, albeit one poised to embrace the fantasy of postracial transcendence to which the ascendance of Obama was giving rise. The media spectacle of this scandal is productively understood in relation to the racially charged term 'baby mama drama' - widely understood slang that positions African American coupledom and out-of-wedlock parenthood as pathologically dysfunctional. It articulates the aforementioned culturally 
entrenched historical discourses that situate black people as lacking in the family values valorized under white hegemony, which are compulsory for the successful articulation of a post-racial identity. As one irreverent definition of the term has it: 'Baby mama probably got pregnant on purpose thinking she could hold on to the man - finds out ain't nothin' happening and gets mad.'16 Noteworthy pop culture reference points for this discourse are Daz Dillinger's 1998 record 'Baby Mama Drama' in which a man bemoans the requirement to make support payments to the mother of his child, who is presented as having filed for child support as a vindictive act following his refusal to marry her; and Dave Hollister's 1999 r'n’b record 'Babymamadrama,' the lyrics for which similarly lament the plight of a man whose personal finances are being drained by his child's mother. Both are analyzed by black popular culture scholar Mark Anthony Neal as symptomatic examples of 'baby mama drama,' which he presents as the structuring discourse of black sexual politics in millennial culture, arguing that it demonizes black single mothers, making appeals to victim status for absent black fathers. ${ }^{17}$

The profile of discursive excoriations of black women through the structuring discourse of 'baby mama drama,' was raised considerably the year before the Murphy/Brown paternity scandal, following the success of the song 'Gold Digger' by hip-hop star Kanye West featuring Hollywood actor Jamie Foxx, the lyrics for which reiterate the discourse thus:

18 years, 18 years

She got one of your kids, got you for 18 years

I know somebody paying child support for one of his kids 
His baby mama's car and crib is bigger than his...

... If you ain't no punk holla we want prenup

WE WANT PRENUP!

It's something that you need to have

'Cause when she leave yo ass she gonna leave with half18

Parallels to be drawn with Murphy's own 'baby mama drama' are striking and clear. 'Baby mama drama' is hence the charged frame through which to understand the gender and racial politics of Murphy/Brown and the furore surrounding the paternity of their daughter Angel Iris Murphy Brown. But to understand how Murphy's persona came to embody these persistent discourses of African American masculinity that characterize black men as promiscuous, misogynist, materialistic irresponsible partners and fathers whose default position is to deny paternity of their children or flee its consequences, it is necessary to observe how he negotiates the politics of coupledom through his celebrity persona over time.

Murphy's twenty-first century 'baby mama drama' vividly recalls the misogynist vitriol, suffused with racial charge, which characterized the better known portions of his 1980s stand-up comedy in the films Delirious (Bruce Gowers, 1983), and especially Raw (Robert Townsend, 1987). Here Murphy infamously rails against what he performatively perceives to be the mercenary sexual machinations of women who deliberately tie themselves to moneyed men, through disingenuous marriage and/or the calculated conception of their children, to obtain wealth and the subsidization of their lifestyles in divorce settlements, and through payment of alimony and child support. Thus, in Raw's 
most famous moment, Murphy delivers a blistering excoriation of African American women: 'They'll get it. They'll get half your money, your house, your car, alimony, child support, and your children.' With its gendered, raced references to the manipulative and/or fraudulent acquisition by black women of unearned assets, this diatribe bears troubling comparison to pejorative 'welfare queen' rhetoric that then characterized Reaganite discourse about the economic dire straits of poor black single mothers. ${ }^{19}$ Thus, through his performed narrative of the breakdown of a romantic relationship via the new archetype of the 'baby mama,' Murphy is complicit in the cultural construction of what Patricia Hill-Collins calls 'controlling images,' of African American femininity, which 'reflect the dominant group's interest in maintaining Black women's subordination.' ${ }^{20}$

In one of many instances that twin his performative persona with the mediation of his personal biography, the strength of Murphy's misogynist feeling was attributed to his recent break-up with then partner Lisa Figueroa. As one journalist reported, 'It was said that Murphy's friends convinced him that she liked his money more than him,' and 'he later said Figueroa inspired Raw's diatribes against grasping, fortune hunting women.'21 The routine takes a more disturbingly gendered, racialized turn as Murphy posits a solution to his coupling dilemma:

If I ever get married, I'd have to go off to the woods of Africa and find me some crazy, naked, zebra bitch that knows nothing about money. She got to be butt naked on a zebra with a big bone in her 
nose and a big plate lip and a big fucked-up Afro... And I'm gonna bring her home and lock her up in the house.

As Herman Beavers notes in his intersectional analysis of Murphy's persona, in Raw Africa is thus construed as 'a primitive and pre-capitalist space' that is also 'synonymous with submissive women' commensurate with the misogyny of Murphy's performance of his conceptualization of the ideal dynamic between a black heterosexual couple. ${ }^{22}$ Making clear what is at stake with respect to the politics of race and gender, Beavers continues:

Murphy asserts that he wants to go to Africa and find Umfufu, the "bush-bitch." But in doing so he works out a contemporary version of the Triangle Trade: he goes to find a woman who lacks the wherewithal to resist or emasculate him [unlike the excoriated but legally enfranchised American women of his divorce settlement tirade]. As a black man who performs the cultural labor of entertaining the masses, Murphy's African woman serves the same purpose as the African American woman in slavery: as a breeder and economic entity subject to his whim."23

Some aspects of this dynamic are vividly realized in the mediation of Murphy's breakup with Brown and the ensuing scandal concerning his alleged, later proven, paternity of their child.

Having divested his persona of this racially charged sexism through his reinvention as a family man, both in films with his successful late 1990s turn 
towards family comedy in lucrative and racially inert vehicles like Dr Dolittle (1998), Daddy Day Care (2003) and The Haunted Mansion (2003), and in his publicity image through media profiles of Murphy with his wife and children, ${ }^{24}$ this modified image began to crack following the breakdown of his marriage. But it unravelled spectacularly after his whirlwind romance with Brown amidst the acrimony of their split. Just weeks after publicly declaring himself 'madly in love' with her, ${ }^{25}$ Murphy abruptly ended the relationship and openly questioned the paternity of the unborn child, ${ }^{26}$ including, famously, in an interview on Dutch television during which he made the statement contained in the epigraph attributed to him at the outset of this chapter. The media framing of the paternity dispute had the recidivist effect of recalling the Eddie Murphy of old, who gleefully performed the above recounted racially charged misogyny, what Bambi L. Haggins describes as 'black on black social critique' devoid of 'larger sociopolitical context,'27 construing women's romantic interest in him and claims of his paternity of their children as predatory and covetous. As the couple entered into a bitter legal dispute, papers filed revealed Murphy's claims that Brown had demanded “a $\$ 9$ million... house, plus living expenses for 18 years in exchange for her silence while she was pregnant."28 In February 2009, Murphy was ordered to pay Brown $£ 7$ million pounds (approximately $\$ 11.4$ million) in child support in monthly instalments until Angel is $18 .^{29}$

Thus, notwithstanding his mid-career interlude in deracinated family comedies and a family-oriented publicity image that chimed well with the shift toward the post-racial, the discourses of coupledom and family that circulate around Murphy's celebrity ultimately fix his public identity in relation to racially charged familial politics. They also invoke some of the worst cultural stereotypes 
of African American masculinity, in stark contrast to the familial idyll of postracial transcendence contemporaneously offered up by the Smiths.

\section{Smith Family Values}

Despite appearing to have followed life scripts that lend themselves to negative, racially charged media framing, by being open about his mistrustfulness of unfaithful women, ${ }^{30}$ fathering a child in a marriage that quickly failed, and fathering another child out of wedlock in subsequent relationship to Pinkett, Smith rose to A-league stardom in the 1990s largely free of imbrication with pernicious discourses of black masculinity that attached themselves to Eddie Murphy (and to which he was complicit in attaching himself). Instead Smith and his second wife, thereafter Jada Pinkett Smith, proved adept in negotiating family values through mediation of their relationship. And, to the extent that by the time Smith was named the most bankable star in Hollywood in 2008, they along with children Jaden and Willow (usefully named after the couple, anchoring their public identities to one another enabling easy brand recognition) were celebrity culture's emblematic black family for America at the dawn of the purportedly post-racial Obama era.

Since his sitcom fantasy of class mobility The Fresh Prince of Bel-Air (NBC 1990-6), Smith's persona had flirted with discourses of racial transcendence. Critics, scholars and audiences have differently attributed the extent of his success to his supposed ability to transcend race and embody masculinity beyond it. Sean Brayton cites Richard Corliss pointing to Smith's 'panracial' popularity as stemming from being black, but considered beyond blackness. ${ }^{31}$ Janani Subramanian states that Smith 'combines contrary qualities that 
simultaneously mark his blackness while foreclosing its narrative significance and... potential political significance.'32 And Lorrie Palmer cites journalism that attributes Smith's crossover appeal to his ability to invoke racial discourse, only to dismiss it, historicise it, or render it irrelevant. ${ }^{33}$ Will Smith's celebrity embodiment of African-American masculinity has always been more racially marked than the innumerable platitudes toward his transcendence of racial discourse were prepared to account for. Much of his success comes from his appearances in a particular kind of African-American star vehicle that Haggins terms the 'comedy of colour-coded colour blindness,' 34 in which a black protagonist is placed in a 'white liberal' 35 narrative context that 'does not engage black culture and identity in any direct or significant manner,'36 but makes superficial gestures to signify race. In Smith's case they are not always comedies, but employ the same devices of racial containment, as can be seen in the laboured musical interludes in I, Robot (2004) and I Am Legend (2007) that confirm Smith's characters' proclivity for black music by having him diegetically listen to records by Stevie Wonder and Bob Marley respectively. Another trope is that the black protagonist is Othered through possession of a 'gift' that 'becomes a mark of difference but also operates as a signifier for identity,'37 for example, Smith's cybernetic arm in I, Robot, his immunity to the deadly virus in $I$ Am Legend, and his superpowers in Hancock (2008). But the emblematic example of the 'comedy of colour-coded colorblindness' for Smith is Hitch (2005), in which he plays Alex Hitchens, a 'date doctor' whose gift is seduction, which is employed to enable the narrative trajectory and romantic relationship of an affluent white couple. 
Furthermore, a noteworthy phenomenon of Smith's screen persona that gives truth to the lie of the fantasies of colorblindness and racial transcendence attached to his celebrity is the nature of his screen coupledom with female costars. Specifically, with exceptions accounted for below, Smith is never (yet) romantically or sexually coupled with white women, commensurate with longstanding cultural fears of miscegenation that excoriate inter-racial coupling between black men and white women through pernicious cultural stereotypes of black male predatory sexuality, and white female virtue and victimhood. A significant exception is CG animation A Shark Tale (2004) in which Smith's character is romantically paired with a character voiced and facially modelled on Renee Zellweger. But the cultural stakes of their inter-racial coupling are nuanced through the film's use (typical in animated family films) of anthropomorphism, which sublimates tensions arising from fears of miscegenation, and is a common device used in animation to negotiate or sidestep questionable politics of identity in characterization. ${ }^{38}$ Another exception is Hancock in which, as trade paper Variety reported during its week of release, Smith plays 'a black man who, at some point in the past, was married to a white woman'39 Industry reporter Peter Bart viewed this as evidence of Hollywood's racial progressivism, noting that this 'story detail... in generations past, would have sent the movie censors into a panic.' ${ }^{40} \mathrm{He}$ thus situates miscegenation anxieties as a phenomenon of history, consigning it to the past in a gesture towards what he understands to be, where screen couples are concerned, the post-racial present.

However, something Bart declines to mention in his generous reading of Hancock's racial politics of coupledom is the anxious manner in which this 
relationship is articulated, and the racially recidivist means by which it is revealed. Smith plays Hancock, an alcoholic ageless amnesiac with superpowers who befriends Ray (Jason Bateman) and his wife Mary (Charlize Theron). Spending the evening at their house Hancock and Mary are drawn together, and with Ray passed out drunk Hancock leans in to kiss her. But before their lips meet, ${ }^{41}$ Mary reveals her own superpowers, grabbing Hancock and violently throwing him through the window (we later learn of their past romance). The implied perceived threat of sexual violence is clear. But thus construed as a plot point, the miscegenation anxieties attendant to the scene are neatly sidestepped as devoid of racial charge. Persistent anxieties over the depiction of this permutation of inter-racial coupling - between black men and white women - is thus a way in which Smith's persona is racially marked, recalling the worst of Hollywood's racist archetypes of black masculinity as sexually threatening to white femininity, in tension with the discourse of post-racial transcendence underpinning his cross-media celebrity.

Off-screen (and occasionally on) the coupledom of Smith and Pinkett Smith has informed their mediation in celebrity culture since reports of their romance surfaced in 1995,42 especially for the latter about whom nary a profile is published that does not hierarchically situate her as the subservient member of this celebrity couple: as 'Mrs Will Smith,'43 'the wife of Will Smith,'44 'Will Smith's other half', 45 etc. This gendered phenomenon is underscored by the fact that Pinkett Smith has been open about her decision to scale down her career and downshift her public sphere expectations of herself following marriage and motherhood. In a 2004 interview she stated that despite the fact that when she met Will she 'wanted to be the biggest female star in the world,' she later realized 
that 'the sacrifice that you have to make, especially as a woman, to live that dream [of normative family life] is going to hit your professional life hard.' ${ }^{46}$ And she was willing to make that downshift because 'My relationship with Will and my family is much too sacred.' ${ }^{47}$ Pinkett Smith thus speaks of the Smith family unit and the relationships therein in reverential pseudo-religious terms, overdetermining their normativity as a functional black family, commensurate with what later becomes the post-racial discursive function of the celebrification of the Obamas. Her noteworthy public sphere downshift can therefore be productively twinned with that of Michelle Obama, whose career as an executive with the University of Chicago Hospitals took a backseat to marriage, motherhood and the campaign trail, following her husband's nomination for the presidency.

Also symptomatic of the Smiths determination to self-present in terms of normative family values is Pinkett Smith's adoption of her husband's last name. In contemporary celebrity culture we are well accustomed to seeing female celebrities eschew this patriarchal tradition. ${ }^{48}$ For the female member of straight celebrity couples, this is often as much about retaining the established brand identity of her celebrity than about making a feminist political gesture. ${ }^{49}$ The case of Jada Pinkett Smith therefore stands out. As such, issues of proprietary nomenclature, gendered celebrity hierarchies and the decision by women in celebrity couples of whether to take their husbands' names come to the discursive fore. In August 2014, Pinkett Smith attracted media attention when she addressed this issue for her fans in a Facebook status update: 
The dilemma you face whether to change your last name to your husband's is a timely one. I have always believed that an empowered woman is one that can stand on her own two feet and has the strength to trust her personal code of womanhood and not necessarily the code that a collective creates as the standard to which an independent woman must adhere to [sic], to actually be identified as...independent. Each woman carries a different code so that she may never be replicated and is assured her individuality and freedom. As long as your decision reflects your personal code towards building the woman you want to be in this world...congrats... ${ }^{50}$

This depoliticized pseudo-feminist rhetoric of personal empowerment, freedom of choice, and individual self-determination is entirely in step with the neoliberal ideological underpinnings of their post-racial discursive function as a celebrity African-American couple and family. And it works to negotiate the recidivist gender politics of patriarchal proprietary nomenclature, and the circular logic of neoliberal self-governance.

At the time of writing, Smith and Pinkett Smith have starred together as a couple onscreen only once in Muhammad Ali biopic Ali (2001), in which Smith plays the iconic boxer. It was not a big box office hit, but it enhanced the cultural capital of his film stardom through industry recognition when it led to his first Academy Award nomination for Best Actor. Pinkett Smith plays Sonji Roi, Ali's first wife (of four), and the romantic screen time they shared here did much to solidify the currency of their celebrity coupledom becoming as it did a 
noteworthy part of the media buzz surrounding the film's release. It also prefigured Smith's later screen pairings with their children, giving rise to the evolution of their celebrity coupledom into a fledgling form of what Rachel Dwyer terms 'dynastic stardom.'51

The Smiths' celebrity coupledom was earlier incorporated into Smith's stardom in 1998, when a heavily pregnant Pinkett Smith appeared in her husband's music video for his record 'Just the Two of Us.' Pinkett Smith rests on the lap of her seated husband, who looks to the camera smiling and stroking her distended belly, while she looks down on him stroking his neck. This laid the foundations for what subsequently became the industrial mobilization of their coupledom and their family dynamic, enabled by the couple's partnership in their production company Overbrook Entertainment, which Smith founded with producer James Lassiter in 1997. This has provided them considerable agency at an industrial level, ensuring their ability to foster the 'dynastic stardom' of their family, through the production of films that they produce and/or in which they and/or their children star. So far they include (but are not limited to): the aforementioned Ali; The Pursuit of Happyness (2006) in which Will and Jaden play father and son in an upward mobility narrative of post-racial transcendence and colorblindness; I Am Legend, a post-racial apocalyptic fantasy in which Will is the emblematic last man on earth and which features Willow playing his daughter in flashback; The Karate Kid (2010) a trans-national narrative of cultural appropriation - a vehicle for Jaden but with Jada on board as producer and taking a lead role in the film's global promotion; and After Earth (2013) which co-stars Will and Jaden, who are billed alongside one another, as father and son. Also significant from this standpoint is Will and Jada's creation of the 
television series All of Us (UPN 2003-6; The CW 2006-7), a sitcom of AfricanAmerican family life which ran for four seasons and was inspired by the Smiths' own 'blended' family dynamic that included Smith's son Trey from his marriage to his first wife Sheree Zampino. The significance of this level of industrial agency to the Smiths' ability to fashion a self-determinedly post-racial image for their familial stardom therefore cannot be overstated.

The over-determination of the Smiths as a model black family for Obama's America has been somewhat destabilized by media reportage in 2013 of their 'open' marriage, which followed celebrity gossip media rumour mongering about Pinkett Smith's alleged sexual affair with pop singer (and then husband to Jennifer Lopez) Marc Anthony in 2011. Since then reportage of the imminent implosion of the Smith marriage has been intermittently recurrent. Alongside this, Smith's heretofore unshakeable box-office bankability has been similarly destabilized following the underperformance and critical excoriation of After Earth, which has been attributed, in part, to backlash against the Smiths' nepotistic championing of their children's stardom. Joseph Tompkins contends that the Smiths' cultivation of Jaden's stardom belies the discourse of meritocracy on which Will's purportedly racially transcendent celebrity was built. ${ }^{2}$ And shifting the focal point of the Smith dynasty to Jaden brings his privilege into view, destabilizing the discourse of meritocracy that has so successfully circulated around Will. How the Smiths will negotiate post-racial familial politics through their celebrity from hereon in remains to be seen. But what is certain is that Smith's celebrity, like Murphy's, is far more tied to the politics of race than any notion of post-racial discourse makes possible, and that this comes into sharp focus through the lens of coupledom and family. 
Thus viewing the racial politics of contemporary celebrity culture through the charged framing discourses of coupledom and family, this chapter therefore illustrates just one of the ways in which we remain far from achieving a culture or society capable of operating without recourse to racialized structures of thought and feeling. What is further revealed by examining the cultural politics of coupling as they manifest through the celebrity identities of African American A-listers like Eddie Murphy and Will Smith is that there remains a very real need to see and acknowledge the continued negotiation of racially charged discourse. Such discourse persists in spite of the disingenuous rise to prominence of postracial notions of racial transcendence and colorblind universalism, and notwithstanding the surface disavowal of racial rhetoric inherent to it that both of these celebrities' identities have at different times adhered to through their respective articulations of family values. Eddie Murphy's sharp fall from public grace following both the Murphy/Brown paternity scandal and his fleeting prior embodiment of the post-racial familial ideal was highly revealing of the extent to which celebrity culture is primed to fall back on familiar cultural scripts underpinned by racial rhetoric, as it leaned heavily on and reached readily for the discourse of 'baby mama drama' to re-anchor his celebrity within racial discourse. And while at the same time Will Smith appeared on the surface to transcend everything that Murphy then embodied with respect to a racially marked celebrity identity, closer interrogation of the way coupledom and family values have been negotiated through his public persona is equally revealing of how tied his celebrity is to race based assumptions about familial cultural politics.

\section{Bibliography}


Bart, Peter. “Superheroes Get Super Makeovers.” Variety, June 30 - July 13, 2008. Brayton, Sean. "The Racial Politics of Disaster and Dystopia in I Am Legend." The Velvet Light Trap 67 (2011): 66-76.

Cashmore, Ellis. Beyond Black: Celebrity and Race in Obama's America. London and New York: Bloomsbury, 2012.

Cobb, Shelley. “Ellen and Portia's Postfeminist Wedding: Celebrity Couples and the Politics of Gay Marriage." In First Comes Love: Power Couples, Celebrity Kinship and Cultural Politics, edited by Shelley Cobb and Neil Ewen. London and New York: Bloomsbury Academic, 2015.

Collins, Nancy. "Big Willie Style.” Rolling Stone, December 10, 1998. Accessed August 10, 2014. http://www.rollingstone.com/movies/news/big-williestyle-19981210?page $=5$

Dwyer, Rachel. “'A Star is Born? Rishi Kapoor and Dynastic Charisma in Hindi Cinema." In First Comes Love: Power Couples, Celebrity Kinship and Cultural Politics, edited by Shelley Cobb and Neil Ewen. London and New York: Bloomsbury Academic, 2015.

“Eddie Murphy Declares He’s ‘Madly In Love’ With Mel.” Hello, September 26, 2006. Accessed September 28, 2014. http://www.hellomagazine.com/film/2006/09/26/eddie-murphy-mel$\mathrm{b} /$

Frazier, E. Franklin. The Negro Family in the United States, Revised and Abridged Edition. New York: The Citadel Press, 1948 [1939].

"Fresh Prince Finds Another Princess." The Voice, November 7, 1995.

Hill-Collins, Patricia. Black Feminist Thought: Knowledge, Consciousness and the 
Politics of Empowerment. New York and London: Routledge, 1991.

Gibbs, Nancy and Michael Scherer. "The Meaning of Michelle.” Time, May 21, 2009. Accessed August 10, 2014.

http://content.time.com/time/magazine/article/0,9171,1900228,00.htm 1.

Gross, Michael. "Big Ed.” Evening Standard Hot Tickets, October 3, 1996.

Haggins, Bambi L. “Laughing Mad: The Black Comedian’s Place in American Comedy of the Post-Civil Rights Era." In Hollywood Comedians: The Film Reader, edited by Frank Krutnik, 171-186. London and New York, 2003.

Hamad, Hannah. “'Hollywood's Hot Dads': Tabloid, Reality and Scandal Discourses of Celebrity Postfeminist Fatherhood." Celebrity Studies 1, no. 2 (2010): 151-169.

Hamad, Hannah. Postfeminism and Paternity in Contemporary U.S. Film: Framing Fatherhood. New York and London: Routledge, 2014.

Husband, Stuart. “Ms Dynamite.” The Sunday Telegraph Magazine, September 2, 2004.

“Is This It?" Guardian Guide, April 21, 2007.

Kantor, Jodi. “The Obamas' Marriage.” The New York Times Magazine, October 29, 2009. Accessed August 10, 2014. http://www.nytimes.com/2009/11/01/magazine/010bama-t.html

Kantor, Jodi. The Obamas: A Mission, A Marriage. London: Allen Lane, 2012.

Neal, Mark Anthony. Soul Babies: Black Popular Culture and the Post-Soul Aesthetic. New York and London: Routledge, 2002.

Nelson, Angela. "Popular Culture in the Age of Obama." In The Iconic Obama, 
2007-2009: Essays on Media Representations of the Candidate and the New President, edited by Nicholas A. Yanes and Derrais Carter, 9-15. Jefferson, North Carolina: McFarland, 2012.

Palmer, Lorrie. "Black Man/White Machine: Will Smith Crosses Over.” The Velvet Light Trap 67 (2011): 28-40.

Pinkett Smith, Jada. Facebook, August 8, 2014. Accessed August 10, 2014. https://www.facebook.com/jada

Rainwater, Lee and William L. Yancey. The Moynihan Report and the Politics of Controversy. Cambridge and London: Harvard University Press, 1967. Rose, Lacey. “Hollywood's Best-Paid Actors.” Forbes, July 22, 2008. Accessed September 28, 2014. http://www.forbes.com/2008/07/22/actorshollywood-movies-biz-media-cx_lr_0722actors.html.

Rutherford, Nick. "Eddie Murphy Ordered to Pay $£ 7$ Million Child Support to Daughter He Had With Mel B.” The Daily Mail, February 8, 2009. Accessed September 28, 2014. http://www.dailymail.co.uk/tvshowbiz/article1138923/Eddie-Murphy-ordered-pay-7million-child-support-daughterMel-B.html

Scheiber, Susan. “Camelot: The PR Campaign.” Zapwater Communications. June 23, 2008. Accessed September 28, 2014. http://blog.zapwater.com/2008/06/

Schneider, Karen S. “Bye-Bye, Bad Boy: Eddie’s in Love.” People, March 22, 1993. “Star Tracks.” People, October 9, 1995. Accessed August 10, 2014. http://www.people.com/people/article/0„20101745,00.html Streeter, Caroline A. “Obama Jungle Fever: Interracial Desire on the Campaign 
Trail." In The Iconic Obama, 2007-2009: Essays on Media Representations of the Candidate and the New President, edited by Nicholas A. Yanes and Derrais Carter, 167-183. Jefferson, NC: McFarland, 2012.

Subramanian, Janani. “Alienating Identification: Black Identity in The Brother from Another Planet and I Am Legend." Science Fiction Film and Television 3, no. 1 (2010): 37-56.

Tay-Tay. "Baby Mama Drama." Urban Dictionary, June 6, 2005. Accessed September 28, 2014. http://www.urbandictionary.com/define.php?term=Baby\%20Mama\%20 Drama

Toppin, Julia. “Home Girl's All Grown Up.” The Voice, September 21, 1998.

“Top Ten Moneymaking Stars of the Past 82 Years.” The 2014 International Motion Picture Almanac. La Jolla, CA, 2014. Accessed August 10, 2014. http://www.quigleypublishing.com/MPalmanac/Top10/Top10_lists.html “Transcript: Illinois Senate Candidate Barack Obama." The Washington Post, July 27, 2004. Accessed September 28, 2014. http://www.washingtonpost.com/wp-dyn/articles/A197512004Jul27.html

Westfall, Sandra Sobieraj. "The Obamas Get Personal.” People, August 4, 2008. Accessed August 10, 2014. http://www.people.com/people/archive/article/0,„20221617,00.html West, Kanye featuring Jamie Foxx. Gold Digger. (C) 2005 by Roc-a-Fella/Def Jam. Digital download.

Wise, Tim. Colorblind: The Rise of Post-Racial Politics and the Retreat from Racial Equity. San Francisco: City Lights Books, 2010. 
1 "Transcript: Illinois Senate Candidate Barack Obama," The Washington Post, July 27, 2004, accessed September 28, 2014, http://www.washingtonpost.com/wp-dyn/articles/A197512004Jul27.html.

${ }^{2}$ Tim Wise, Colorblind: The Rise of Post-Racial Politics and the Retreat from Racial Equity (San Francisco: City Lights Books, 2010), 16.

${ }^{3}$ Lacey Rose, “Hollywood's Best-Paid Actors," Forbes, July 22, 2008, accessed September 28, 2014, http://www.forbes.com/2008/07/22/actors-hollywood-movies-biz-mediaCx_lr_0722actors.html.

4 "Top Ten Moneymaking Stars of the Past 82 Years," The 2014 International Motion Picture Almanac (La Jolla, CA: Quigley Publishing, 2014), accessed August 10, 2014, http://www.quigleypublishing.com/MPalmanac/Top10/Top10_lists.html ${ }^{5}$ Rose, "Hollywood's Best-Paid Actors."

6 "Top Ten Moneymaking Stars of the Past 82 Years."

${ }^{7}$ Ellis Cashmore, Beyond Black: Celebrity and Race in Obama's America (London and New York: Bloomsbury, 2012), 2.

${ }^{8}$ Nancy Gibbs and Michael Scherer, “The Meaning of Michelle," Time, May 21, 2009, accessed August 10, 2014, http://content.time.com/time/magazine/article/0,9171,1900228,00.html. 9 Jodi Kantor, “The Obamas' Marriage," The New York Times Magazine, October 29, 2009, accessed August 10, 2014, http://www.nytimes.com/2009/11/01/magazine/010bama-t.html. This was later expanded into and released as a full length book.

${ }^{10}$ Sandra Sobieraj Westfall, "The Obamas Get Personal," People, August 4, 2008, accessed August 10, 2014, http://www.people.com/people/archive/article/0,20221617,00.html.

${ }^{11}$ Susan Scheiber, “Camelot: The PR Campaign,” Zapwater Communications, June 23, 2008, accessed September 28, 2014, http://blog.zapwater.com/2008/06/

${ }^{12}$ Caroline A. Streeter, "Obama Jungle Fever: Interracial Desire on the Campaign Trail," in The Iconic Obama, 2007-2009: Essays on Media Representations of the Candidate and New President, ed. Nicholas A. Yanes and Derrais Carter (Jefferson, North Carolina: McFarland, 2012), 177. 
${ }^{13}$ Angela Nelson, "Popular Culture in the Age of Obama," in The Iconic Obama, 2007-2009: Essays on Media Representations of the Candidate and New President, ed. Nicholas A. Yanes and Derrais Carter (Jefferson, NC: McFarland, 2012), 13.

${ }^{14}$ E. Franklin Frazier, The Negro Family in the United States, Revised and Abridged Edition (New York: The Citadel Press, 1948 [1939]).

${ }^{15}$ Lee Rainwater and William L. Yancey, The Moynihan Report and the Politics of Controversy (Cambridge and London: Harvard University Press, 1967).

16 Tay-Tay, “Baby Mama Drama”, Urban Dictionary, June 6, 2005, accessed September 28, 2014, http://www.urbandictionary.com/define.php?term=Baby\%20Mama\%20Drama

17 Mark Anthony Neal, Soul Babies: Black Popular Culture and the Post-Soul Aesthetic (New York and London: Routledge, 2002), 77-85.

${ }^{18}$ Kanye West featuring Jamie Foxx, Gold Digger $\odot 2005$ by Roc-a-Fella, Def Jam, digital download. ${ }^{19}$ Ibid., 75-76.

${ }^{20}$ Patricia Hill-Collins, Black Feminist Thought: Knowledge, Consciousness and the Politics of Empowerment (New York and London: Routledge, 1991), 71.

${ }^{21}$ Michael Gross, “Big Ed," Evening Standard Hot Tickets, October 3, 1996, 3.

${ }^{22}$ Herman Beavers, “The Cool Pose': Intersectionality, Masculinity, and Quiescence in the Comedy and Films of Richard Pryor and Eddie Murphy," in Race and the Subject of Masculinities, eds. Harry Stecopoulos and Michael Uebel (Durham and London: Duke University Press, 1997), 265.

${ }^{23}$ Ibid., 265-6.

${ }^{24}$ Karen S. Schneider, “Bye-Bye, Bad Boy: Eddie's in Love," People, March 22, 1993, 71. See also Hannah Hamad, Postfeminism and Paternity in Contemporary U.S. Film: Framing Fatherhood (New York and London: Routledge, 2014), 124-128, and Hamad, “'Hollywood's Hot Dads': Tabloid, Reality and Scandal Discourses of Celebrity Post-feminist Fatherhood," Celebrity Studies 1, no. 2 (2010): 151-169.

25 “Eddie Murphy Declares He’s 'Madly In Love' With Mel," Hello, September 26, 2006, accessed September 28, 2014, http://www.hellomagazine.com/film/2006/09/26/eddie-murphy-mel-b/ 
${ }^{26}$ Marla Lehner, “Eddie Murphy Questions Paternity of Mel B’s Baby,” People, May 12, 2006, accessed September 28, 2014, http://www.people.com/people/article/0,1566035,00.html ${ }^{27}$ Bambi L. Haggins, “Laughing Mad: The Black Comedian’s Place in American Comedy of the Post-Civil Rights Era," in Hollywood Comedians: The Film Reader, ed. Frank Krutnik (London and New York: Routledge, 2003),

28 “'I Won't See My Daughter Because Mel B Tricked Me Into Having a Baby' Says Eddie Murphy," The Daily Mail, March 14, 2008, accessed September 28, 2014,

http://www.dailymail.co.uk/tvshowbiz/article-533139/I-wont-daughter-Mel-B-tricked-havingbaby-says-Eddie-Murphy.html

${ }^{29}$ Nick Rutherford, "Eddie Murphy Ordered to Pay $€ 7$ Million Child Support to Daughter He Had With Mel B," The Daily Mail, February 8, 2009, accessed September 28, 2014, http://www.dailymail.co.uk/tvshowbiz/article-1138923/Eddie-Murphy-ordered-pay-7millionchild-support-daughter-Mel-B.html

${ }^{30}$ Nancy Collins, "Big Willie Style," Rolling Stone 801, December 10, 1998, accessed August 10, 2014, http://www.rollingstone.com/movies/news/big-willie-style-19981210?page=5.

${ }^{31}$ Sean Brayton, "The Racial Politics of Disaster and Dystopia in I Am Legend," The Velvet Light Trap 67 (2011): 75.

32 Janani Subramanian, "Alienating Identification: Black Identity in The Brother from Another Planet and I Am Legend," Science Fiction Film and Television 3, no. 1 (2010): 45.

${ }^{33}$ Lorrie Palmer, "Black Man/White Machine: Will Smith Crosses Over," The Velvet Light Trap 67 (2011): 34 .

${ }^{34}$ Haggins, "Laughing Mad," 178.

35 Ibid., 181.

${ }^{36}$ Ibid.

37 Ibid.

${ }^{38}$ See for example Murphy's racially marked vocal performance as the jive-talking Donkey in the Shrek films $(2001,2004,2007,2010)$ and the sublimation of the 'Mammy' archetype into Gloria the hippo voiced by Pinkett Smith in the Madagascar films (2005, 2008, 2012).

${ }^{39}$ Peter Bart, “Superheroes Get Super Makeovers," Variety, June 30 - July 13, 2008, 3. 
${ }^{40}$ Ibid., 3.

${ }^{41} \mathrm{An}$ alternative version of the scene was shot and cut in which the characters engage in a lengthy kiss, but it was edited out for the film's release.

42 "Star Tracks," People, October 9, 1995, accessed August 10, 2014, http://www.people.com/people/article/0,20101745,00.html; “Fresh Prince Finds Another Princess," The Voice, November 7, 1995, 27.

43 Julia Toppin, “Home Girl’s All Grown Up,” The Voice, September 21, 1998, 41.

${ }^{44}$ Stuart Husband, "Ms Dynamite," The Sunday Telegraph Magazine, September 2, 2004, 25.

45 “Is This It?” Guardian Guide, April 21, 2007, 98.

${ }^{46}$ Husband, "Ms Dynamite," 25.

${ }^{47}$ Ibid., 25.

${ }^{48}$ British 'WAGs', discussed in the introduction to this volume are a noteworthy exception to this.

${ }^{49}$ For discussion of this issue as politically charged see in this volume Shelley Cobb, "Ellen and Portia's Postfeminist Wedding: Celebrity Couples and the Politics of Gay Marriage," in First Comes Love: Power Couples, Celebrity Kinship and Cultural Politics, eds. Shelley Cobb and Neil Ewen (London and New York: Bloomsbury, 2015).

50 Jada Pinkett Smith, Facebook, August 8, 2014, accessed August 10, 2014, https://www.facebook.com/jada.

${ }^{51}$ See in this volume, Rachel Dwyer, "'A Star is Born? Rishi Kapoor and Dynastic Charisma in Hindi Cinema," in First Comes Love, eds. Cobb and Ewen.

52 Joseph Tompkins, e-mail message to author, November 2, 2013. 